Supplement of Hydrol. Earth Syst. Sci., 19, 1193-1207, 2015

http://www.hydrol-earth-syst-sci.net/19/1193/2015/

doi:10.5194/hess-19-1193-2015-supplement

(C) Author(s) 2015. CC Attribution 3.0 License.

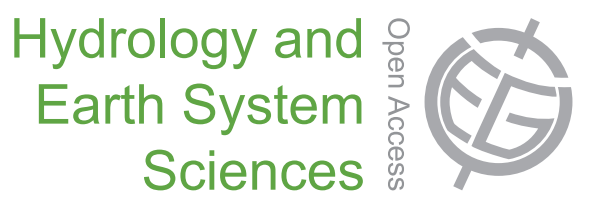

(c) (i)

Supplement of

\title{
Use of field and laboratory methods for estimating unsaturated hydraulic properties under different land uses
}

S. Siltecho et al.

Correspondence to: C. Hammecker (claude.hammecker@ird.fr) 


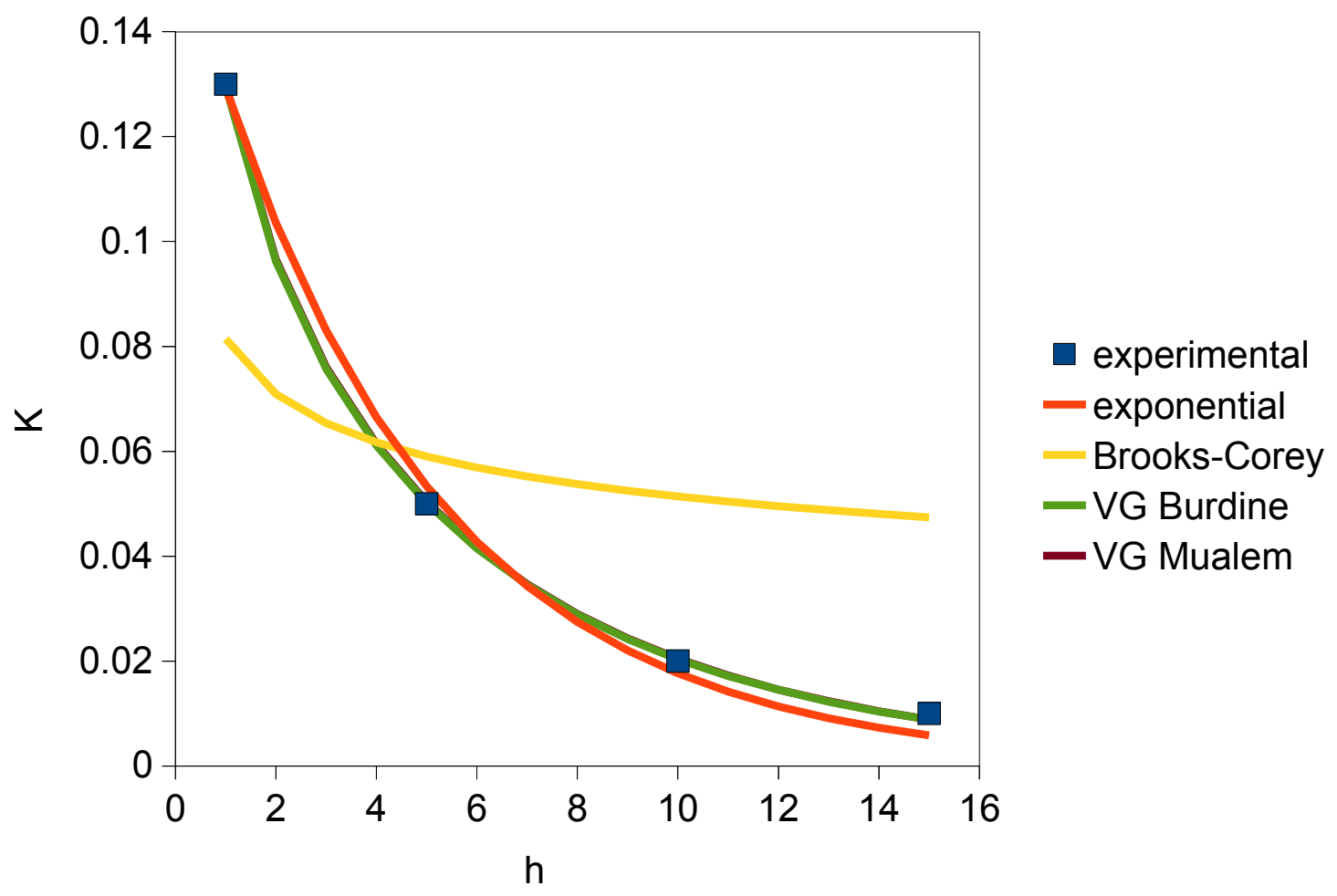

\begin{tabular}{lc}
\hline model & Ks \\
\hline exponential & 0.16 \\
Brooks and Corey & 0.11 \\
Van Genuchten Burdine & 0.29 \\
Van Genuchten Mualem & 0.5 \\
\hline
\end{tabular}

For given experimental values, the fitted saturated hydraulic conductivity with the different models show important variability. 